\section{Morphological Changes of Mexican Native Succulent Plants in a Vertical Greenery System Compared with Pot Conditions}

\author{
Carlos Efraín Reyes-González ${ }^{1}$, José Pablo Torres-Morán², \\ Blanca Catalina Ramírez-Hernández ${ }^{3}$, Liberato Portillo ${ }^{4}$, \\ Enrique Pimienta-Barrios ${ }^{1}$, and Martha Isabel Torres-Morán ${ }^{1,5}$
}

ADDITIONAL INDEX WORDs. stonecrops, green walls, plant adaptation capacity

Summary. Adaptation parameters as leaf width, leaf length, mesophyll thickness, number of adaxial and abaxial stomata, and biomass were measured in eight stonecrop species (Crassulaceaae), spider plant (Chlorophytum comosum), and maria's heart (Peperomia tepoztecoana) in vertical greenery system (VGS) and containers (POT). Statistical significance among parameters was probed by $t$ test and principal component analysis was performed to detect global morphological changes. Mexican gem (Echeveria elegans), graptosedum ( $\times$ Graptosedum 'Vera Higgins'), lavender scallops (Kalanchoe fedtschenkoi), coppertone sedum (Sedum nussbaumerianum), ghost plant (Graptopetalum paraguayense), and jelly-beans (Sedum rubrotinctum) were the species that did not change significantly their morphological traits during growth in the VGS. This provides evidence of the potential for these species to be used in green walls or any VGS while maintaining their characteristic shape and beauty. Graptopetalum (Graptopetalum macdougalli), gray sedum (Sedum griseum), maria's heart, and spider plant showed changes in its morphology during growth in the VGS when compared with growth in POT, indicating a lower potential for adaption to VGS.

$\mathrm{T}$ The scarcity of green areas in urban zones and problems caused by environmental pollution have led to the investigation of alternatives to improve the relationship between human health and plants in urban areas (Gasperi et al., 2015). Even in countries of low socioeconomic status, people enjoy being surrounded by green spaces and cultivate plants to provide spices, condiments, food, and beauty (Wolf, 2015). Growing plants in dense urban areas is possible in part because of the

\footnotetext{
${ }^{1}$ Departamento de Producción Agrícola, Centro Universitario de Ciencias Biológicas y Agropecuarias, Universidad de Guadalajara, Camino Ramón Padilla Sánchez No. 2100, Nextipac, Zapopan, Jalisco 45110, Mexico

${ }^{2}$ Departamento de Desarrollo Sustentable, Centro Universitario de Ciencias Biológicas y Agropecuarias, Universidad de Guadalajara, Camino Ramón Padilla Sánchez No. 2100, Nextipac, Zapopan, Jalisco 45110 , Mexico

${ }^{3}$ Departamento de Ecología, Centro Universitario de Ciencias Biológicas y Agropecuarias, Universidad de Guadalajara, Camino Ramón Padilla Sánchez No. 2100, Nextipac, Zapopan, Jalisco 45110, Mexico

${ }^{4}$ Departamento de Botánica y Zoología, Centro Universitario de Ciencias Biológicas y Agropecuarias, Universidad de Guadalajara, Camino Ramón Padilla Sánchez No. 2100, Nextipac, Zapopan, Jalisco 45110, Mexico

${ }^{5}$ Corresponding author. E-mail: isabel.torres@academicos. udg.mx.
}

https://doi.org/10.21273/HORTTECH03988-18 invention by French botanist Patrick Blanc, who applied the term mur végétal (green wall) to a botanical and structural system for greening buildings (Blanc, 2008). Subsequently, researchers in urban geography, architecture, and landscape planning have been studying this form of plant production and have defined arrangements allowing vertical cultivation as green infrastructure [GI (Pérez et al., 2014)].

Green structures can be classified as an interconnected network of natural and seminatural elements capable of providing multiple functions and ecosystem services (Bartesaghi-Koc et al., 2017; Coma et al., 2016). This concept includes many different aspects and must consider a high number of variables such as the type of supporting materials, control of water, nutrients, and plants (Perini et al.,
2011). Authors Medl et al. (2017) studied the structure and sustainable vegetation layer in shotcrete walls adjacent to road environments. They reported green walls as a promising technique in terms of establishing an optimal vegetation cover on vertical structures along roads built where there are slopes that can erode and wash away causing landslides and avalanches.

The benefits of greening buildings are well known, principally regarding water use and energy savings in extreme climates (McFarland, 2017; Timur and Karaca, 2013; van den Berg and van den Berg, 2015), but there is a need to increase the set of native plants with potential to be used in green vertical structures and buildings.

One of the reasons for adapting native plants to a new cropping system as a green roof or green wall was reported by Razzaghmanesh et al. (2014) in a study of the ecological aspects of green roofs in response to hot dry summer conditions. The benefits and adaptation of some native species were considered and evaluated, with the results showing that native succulent species could best tolerate that local climate conditions and had a $100 \%$ survival rate compared with other species. Stonecrops offer creative and aesthetic potential as well as high adaptation capacity (Lüttge, 2004). Succulent plants can also resist periods of prolonged drought (Nagase and Dunnett, 2010). Wholeplant growth and competitive ability of succulents depend not only on the photosynthetic rate of individual leaves but also on the geometry and dynamics of its canopy (Givnish, 1988). The use of plants in outdoor and indoor walls has an aesthetical feature. Covering the wall with plants is possible through a modular living wall system as reported by Manso and Castro-Gomes (2015) that implies the use of trays, vessels, planter tiles, and flexible bags. A VGS [according to classification reported by

\begin{tabular}{llll}
\hline $\begin{array}{l}\text { Units } \\
\text { To convert U.S. to SI, } \\
\text { multiply by }\end{array}$ & U.S. unit & SI unit & $\begin{array}{l}\text { To convert SI to U.S., } \\
\text { multiply by }\end{array}$ \\
\hline 0.3048 & $\mathrm{ft}$ & $\mathrm{m}$ & 3.2808 \\
2.54 & inch $(\mathrm{es})$ & $\mathrm{cm}$ & 0.3937 \\
25.4 & inch $(\mathrm{es})$ & $\mathrm{mm}$ & 0.0394 \\
1 & $\mu \mathrm{mho} / \mathrm{cm}$ & $\mu \mathrm{S} \cdot \mathrm{cm}^{-1}$ & 1 \\
28.3495 & $\mathrm{Oz}$ & $\mathrm{g}$ & 0.0353 \\
1 & $\mathrm{ppm}$ & $\mathrm{mg} \cdot \mathrm{L}^{-1}$ & 1 \\
$\left({ }^{\circ} \mathrm{F}-32\right) \div 1.8$ & ${ }^{\circ} \mathrm{F}$ & ${ }^{\circ} \mathrm{C}$ & $\left({ }^{\circ} \mathrm{C} \times 1.8\right)+32$
\end{tabular}


Bartesaghi-Koc et al. (2017)], offers flexibility in size and maintenance. Stonecrops may have the potential to grow in VGS with low water demand in a dry environment. Mexico has endemic species, which can offer this alternative. In the present work, parameters of adaptation to a VGS of native stonecrop species were tested.

\section{Materials and Methods}

Plant material and treatments. The experiment was conducted at Centro Universitario de Ciencias Biológicas y Agropecuarias (CUCBA), located in Rancho Las Agujas, Zapopan, Mexico, in the central part of Jalisco state, between lat. $20^{\circ} 25^{\prime} 30^{\prime \prime} \mathrm{N}$ and $20^{\circ} 57^{\prime} 00^{\prime \prime} \mathrm{N}$, long. $103^{\circ} 19^{\prime} 30^{\prime \prime} \mathrm{W}$ and $103^{\circ} 39^{\prime} 20^{\prime \prime} \mathrm{W}$. This site is $1548 \mathrm{~m}$ above sea level and the average annual precipitation is $906 \mathrm{~mm}$.

The species, mexican gem, graptopetalum, ghost plant, graptosedum, gray sedum, coppertone sedum, jellybeans, lavender scallops, spider plant, and maria's heart were used. Plant material was acquired from the CUCBA nursery, which has a collection of southern and central Mexico. These regions can be classified as warm temperate climate with dry winter, according to Köppen and Geiger climate classification update map (Kottek et al., 2006). All species are represented in Fig. 1. Plants of each species were selected for uniformity based on specific species shape, age, length of plant, and number of branches and were then further divided into three groups of 15 plants, disposed randomly into one of two treatments consisting the first (VGS) in three independent square structures of $25 \times 35$ inches with a double layer of geotextile, which is soilless and without irrigation system (Fig. 2). The second treatment consisted of same number of plants of each species grown in 4-inchdiameter plastic POT with $800 \mathrm{~cm}^{3}$ volume with a substrate mix of $70 \%$ $\mathrm{v} / \mathrm{v}$ peatmoss and $30 \%$ fine pumice. No fertilizers were used. Both treatments were placed outdoors in shadecloth (50\%) under the same conditions during springtime. The experiment was performed over a 90-d period (March to May). The comparison of treatments is shown in Fig. 3. The daily light integral was $5.5 \mathrm{~mol} \cdot \mathrm{m}^{-2} \cdot \mathrm{d}^{-1}$, air temperature was $12.7^{\circ} \mathrm{C}$ minimum and $36{ }^{\circ} \mathrm{C}$ maximum (average $34.5{ }^{\circ} \mathrm{C}$ ), and the relative humidity was $67 \%$.

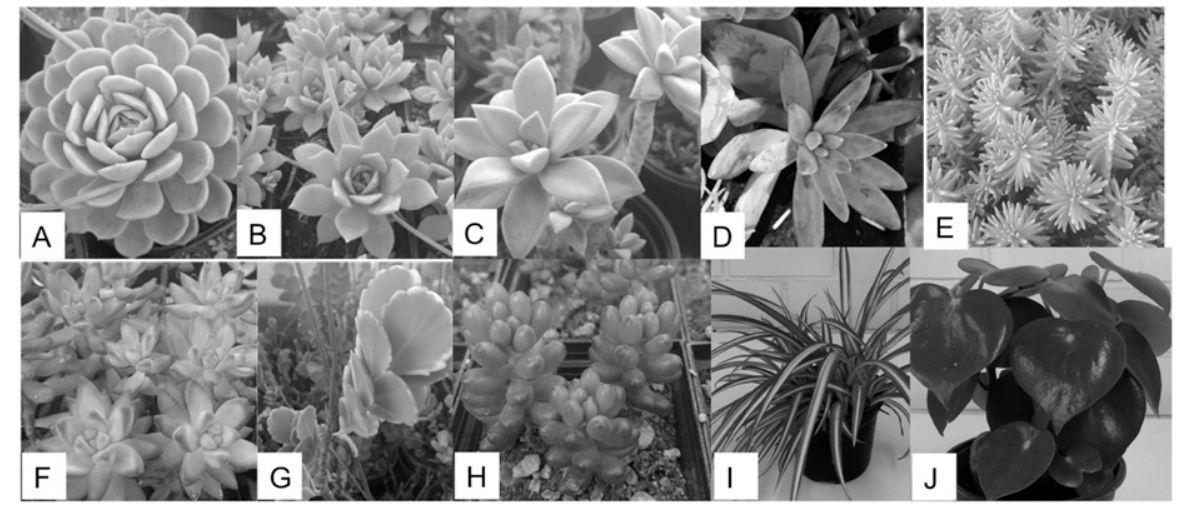

Fig. 1. A sample of shape and canopy of species used: (A) mexican gem, (B) graptopetalum, (C) ghost plant, (D) graptosedum, (E) gray sedum, (F) coppertone sedum, (G) lavender scallops, (H) jelly-beans, (I) spider plant, (J) maria's heart.



Fig. 2. Vertical greenery system diagram, materials used for its construction; 1 inch $=2.54 \mathrm{~cm}$.

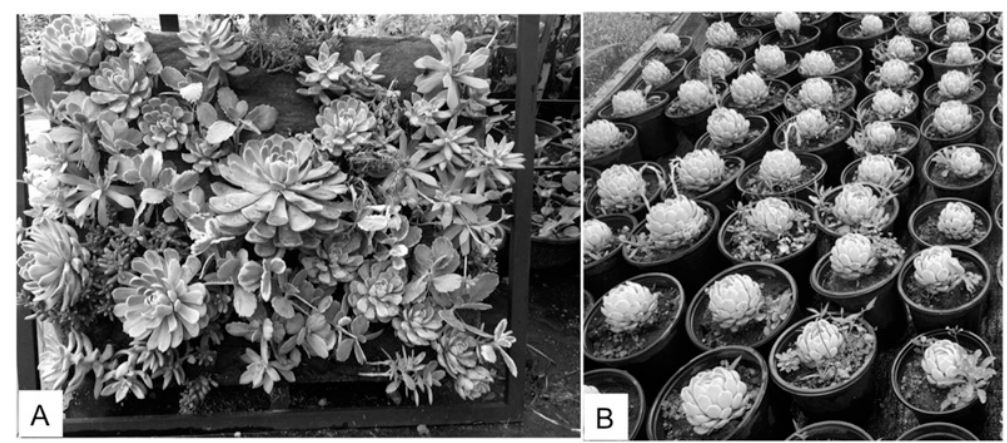

Fig. 3. Overview of systems used as treatments: (A) vertical greenery system, (B) containers.

The same volume of water was provided to VGS and POT system once daily with tap water. The tap water had a $\mathrm{pH}$ value of 6.9 , electrical conductivity values of $0.27 \mu \mathrm{S} \cdot \mathrm{cm}^{-1}$, total dissolved solids of $230 \mathrm{ppm}, 800$ ppm of alkaline elements (bicarbonatesodium), and $0.36 \mathrm{mg} \cdot \mathrm{L}^{-1}$ fluorides. 
Parameter and data analysis. An independent-samples $t$ test was conducted to compare morphological traits (variables) of species grown in VGS and POT. The morphological traits measured were leaf width, leaf length, and mesophyll thickness to detect changes in leaf size. To obtain leaf data for shrub plants, the leaf partial hardening part was chosen, and for rosette shape, the middle part leaf, not the apical and not the basis leaf. The numbers of adaxial and abaxial stomata were obtained to detect changes in adaptation. Data were obtained using clear nail varnish to make an impression of the epidermis in glass slides and coverslips. Impressions were observed on a stereoscopic microscope with $\times 40$ objective. Biomass data were obtained by puncturing a tissue fragment from selected leaves; these samples were weighed before and after oven-drying at $60{ }^{\circ} \mathrm{C}$. A principal component analysis with morphological traits as well as stomata and biomass was performed using NTSYS-pc software [version 2.1 (Rohlf, 2009)] to compare at the same time in each species all parameters and both treatments (VGS and POT).

\section{Results and Discussion}

Morphological traits. The species tested had differential responses in terms of morphological traits. According to the capacity of a single genotype to produce functionally appropriate phenotypes in different environments (Bradshaw and Hardwick, 1989; Sultan, 1995), the differences observed in both production systems (VGS and POT) offer an alternative picture of plant adaptation. Table 1 shows the results of statistical $t$ test for each species. In terms of leaf size traits (width and length), there were no statistical significant differences $(P>0.5)$ between growth in the VGS or in POT for mexican gem, graptosedum, lavender scallops, gray sedum, coppertone sedum, and spider plant, but there were statistical significant differences $(P<$ 0.05 ) for graptopetalum that had bigger leaves in POT and ghost plant that had bigger leaves in VGS. These results show how individual plants respond to different systems in the short term. Responses in leaf anatomy have been reported in several works with stonecrops and other succulents as an indicator to adaptation such as

Table 1. Means and significance of $t$ test for morphological traits of eight species of stonecrops, spider plant, and maria's heart in vertical greenery system (VGS) and containers (POT).

\begin{tabular}{|c|c|c|c|c|c|c|}
\hline \multirow{3}{*}{$\begin{array}{l}\text { Species and } \\
\text { treatment }\end{array}$} & \multirow{3}{*}{$\begin{array}{l}\text { Mesophyll } \\
\text { thickness } \\
(\mathrm{cm})^{\mathrm{z}}\end{array}$} & \multicolumn{2}{|c|}{ Leaf } & \multirow{2}{*}{\multicolumn{2}{|c|}{ Stomata (no.) }} & \multirow{3}{*}{$\begin{array}{c}\text { Biomass } \\
(\mathrm{g})^{\mathrm{z}}\end{array}$} \\
\hline & & \multirow{2}{*}{$\begin{array}{c}\text { Width } \\
(\mathrm{cm})\end{array}$} & \multirow{2}{*}{$\begin{array}{c}\text { Length } \\
(\mathrm{cm})\end{array}$} & & & \\
\hline & & & & Adaxial & Abaxial & \\
\hline \multicolumn{7}{|l|}{ Mexican gem } \\
\hline VGS & 0.48 & 1.31 & 2.58 & 2.20 & 2.80 & 0.026 \\
\hline \multirow[t]{2}{*}{ POT } & 0.48 & 1.36 & 2.52 & 6.20 & 4.40 & 0.023 \\
\hline & NS & NS & NS & $* *$ & $* *$ & * \\
\hline \multicolumn{7}{|c|}{ Graptopetalum } \\
\hline VGS & 0.53 & 1.05 & 2.61 & 3.20 & 1.20 & 0.012 \\
\hline \multirow[t]{2}{*}{ POT } & 0.40 & 1.33 & 2.99 & 1.20 & 2.00 & 0.0125 \\
\hline & NS & $* *$ & $* *$ & $* *$ & $* *$ & NS \\
\hline \multicolumn{7}{|l|}{ Ghost plant } \\
\hline VGS & 0.61 & 1.49 & 3.31 & 4.00 & 2.40 & 0.021 \\
\hline \multirow[t]{2}{*}{ POT } & 0.55 & 1.23 & 2.76 & 4.40 & 2.20 & 0.029 \\
\hline & $* *$ & $* *$ & $* *$ & NS & NS & $* *$ \\
\hline \multicolumn{7}{|l|}{ Graptosedum } \\
\hline VGS & 0.55 & 0.89 & 2.51 & 3.00 & 3.00 & 0.014 \\
\hline \multirow[t]{2}{*}{ POT } & 0.48 & 1.57 & 2.50 & 5.60 & 5.20 & 0.013 \\
\hline & NS & NS & NS & $* *$ & $* *$ & $* *$ \\
\hline \multicolumn{7}{|c|}{ Lavender scallops } \\
\hline VGS & 0.23 & 2.32 & 3.86 & 10.00 & 7.4 & 0.004 \\
\hline \multirow[t]{2}{*}{ POT } & 0.28 & 2.21 & 3.61 & 11.40 & 7.8 & 0.005 \\
\hline & NS & NS & NS & NS & NS & $* *$ \\
\hline \multicolumn{7}{|l|}{ Gray sedum } \\
\hline VGS & 0.10 & 0.10 & 0.92 & 14.75 & 8.80 & 0.100 \\
\hline \multirow[t]{2}{*}{ POT } & 0.10 & 0.10 & 0.93 & 17.25 & 4.60 & 0.160 \\
\hline & NS & NS & NS & NS & $* *$ & $* *$ \\
\hline \multicolumn{7}{|c|}{ Coppertone sedum } \\
\hline VGS & 0.52 & 1.04 & 3.31 & 9.20 & 8.80 & 0.022 \\
\hline \multirow[t]{2}{*}{ POT } & 0.52 & 1.03 & 3.27 & 11.60 & 8.60 & 0.027 \\
\hline & NS & NS & NS & NS & NS & $* *$ \\
\hline \multicolumn{7}{|l|}{ Jelly-beans } \\
\hline VGS & 0.35 & 0.35 & 1.19 & 3.80 & 7.20 & 0.011 \\
\hline \multirow[t]{2}{*}{ POT } & 0.32 & 0.32 & 1.24 & 3.40 & 3.20 & 0.009 \\
\hline & NS & * & NS & NS & ** & * \\
\hline \multicolumn{7}{|l|}{ Spider plant } \\
\hline VGS & 0.41 & 11.10 & 144.31 & 1.20 & 17.80 & 0.001 \\
\hline POT & 0.39 & 11.51 & 148.59 & 0.00 & 14.40 & 0.000 \\
\hline & NS & NS & NS & $* *$ & * & $* *$ \\
\hline Maria's heart & & & & & & \\
\hline VGS & 1.10 & 44.65 & 52.93 & 5.80 & 14.60 & 0.017 \\
\hline POT & 0.77 & 65.11 & 83.39 & 2.00 & 11.60 & 0.014 \\
\hline & $* *$ & ** & ** & $* *$ & $* *$ & ** \\
\hline
\end{tabular}

${ }^{\mathrm{z}} 1 \mathrm{~cm}=0.3937$ inch, $1 \mathrm{~g}=0.0353 \mathrm{oz}$.

Ns, ${ }^{*},{ }^{* *}$ Nonsignificant or significant at $P \leq 0.05$ or 0.01 , respectively.

change in size or stomata density per area (Silva et al., 2009; Teeri et al., 1981). Results for some species indicated no morphological change, which could be because the plants adapt to the soilless cultivation in the geotextile that makes up the VGS. The leaf thickness of the cuticle remained without significant difference in almost all species. However, in VGS maria's heart and ghost plant, leaf thickness increased by $42 \%$ and $10 \%$, respectively. These results could be probably due to the easy absorption of water from the geotextile layer and the consequent storage in their leaves. Variations in leaf anatomy such as mesophyll thickness are indicative of adaptation (Nobel et al., 1975; Silva et al., 2014) and quantitative differences in leaf thickness response among species have a genetic basis (Teeri et al., 1981).

In VGS mexican gem, graptosedum, jelly-beans, spider plant, and maria's heart produced more biomass 
and ghost plant, lavender scallops, gray sedum, and coppertone sedum produced less biomass. Graptopetalum showed no significant differences $(P>0.05)$. The production of biomass is an indicator of the operation of the plant in terms of energy accumulation in the form of carbohydrates (Abrahamson and Caswell, 1989); this fact supports the adaptation potential of mexican gem, graptosedum, jelly-beans, spider plant, and maria's heart to VGS.

Adaxial and abaxial stomata. Some species showed differences in the number of stomata (Figs. 3 and 4). Both abaxial and adaxial stomata were lower in the VGS for graptosedum, mexican gem, spider plant, and maria's heart. Stomatal density depends on environmental conditions, leaf area, and leaf position (Gay and Hurd, 1975), which might explain the response of the species observed here. Graptopetalum growing in VGS increased its number of abaxial stomata but decreased adaxial stomata. This behavior could be related to differences in water availability because in many cases, water restriction reportedly reduces the number of stomata (Silva et al., 2014) and the capacity of species to manage resource allocation. The differences in stomatal density occurred because of discontinuities both within and between species and genera (Figs. 4 and 5). This study clearly showed that the number of stomata changed in leaves of plants growing in the two different systems. As reported by AbdulRahaman et al. (2014), stomata are an important organelle and are useful for determining adaptation (Brzezicka et al., 2015; Hetherington and Woodward, 2003).

Principal component analysis. The principal component analysis allows comparing all traits simultaneously and showed the morphological response of individual plants of each species to POT and VGS. The eigenvalues of the correlation matrix calculated show that the first four components explained $95.67 \%$ of the variation among species and treatment. The score of principal component 1 (SCPl) was obtained. The significant positive variables $(r>0.5)$ for this component were VGS biomass, POT biomass, VGS adaxial stomata, and POT adaxial stomata. In the score of principal component 2 (SCP2), the significant positive variables were VGS adaxial stomata, VGS

Abaxial leaf surface
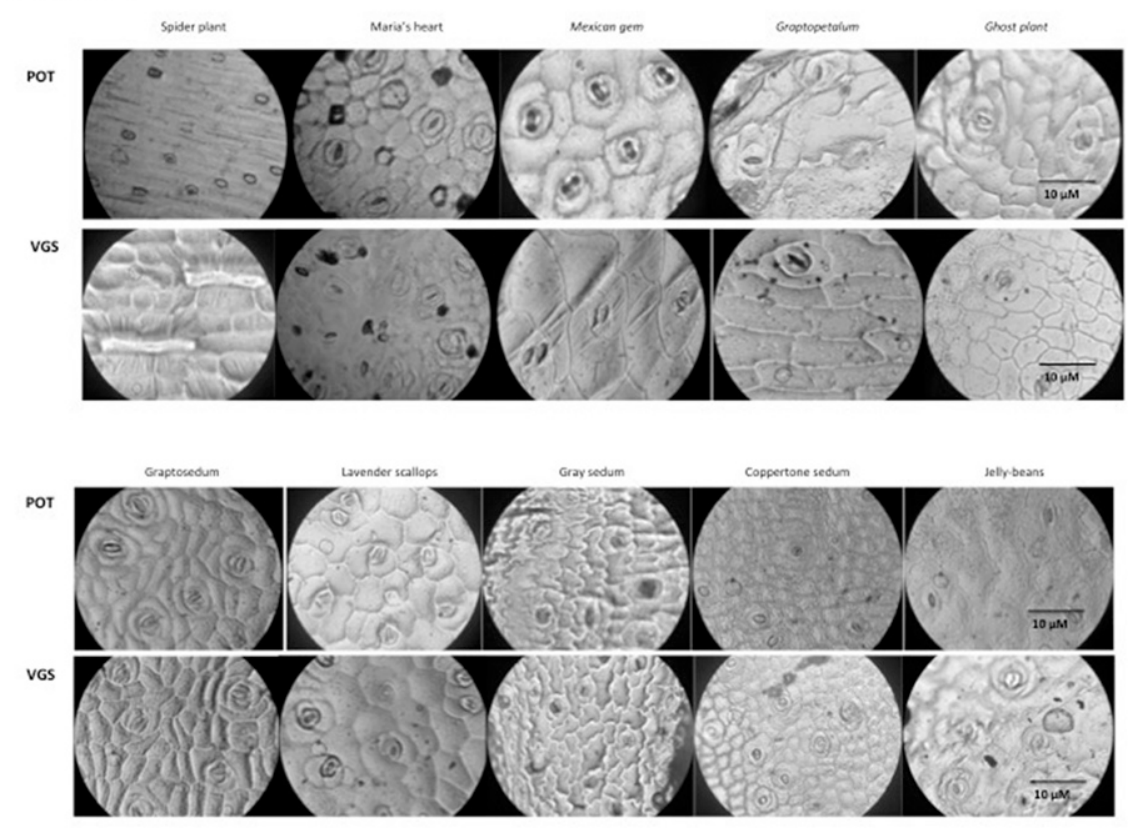

Fig. 4. Differences between stomata number in vertical greenery system (VGS) and containers (POT) for abaxial (upper) leaf surface in spider plant, maria's heart, and stonecrop.
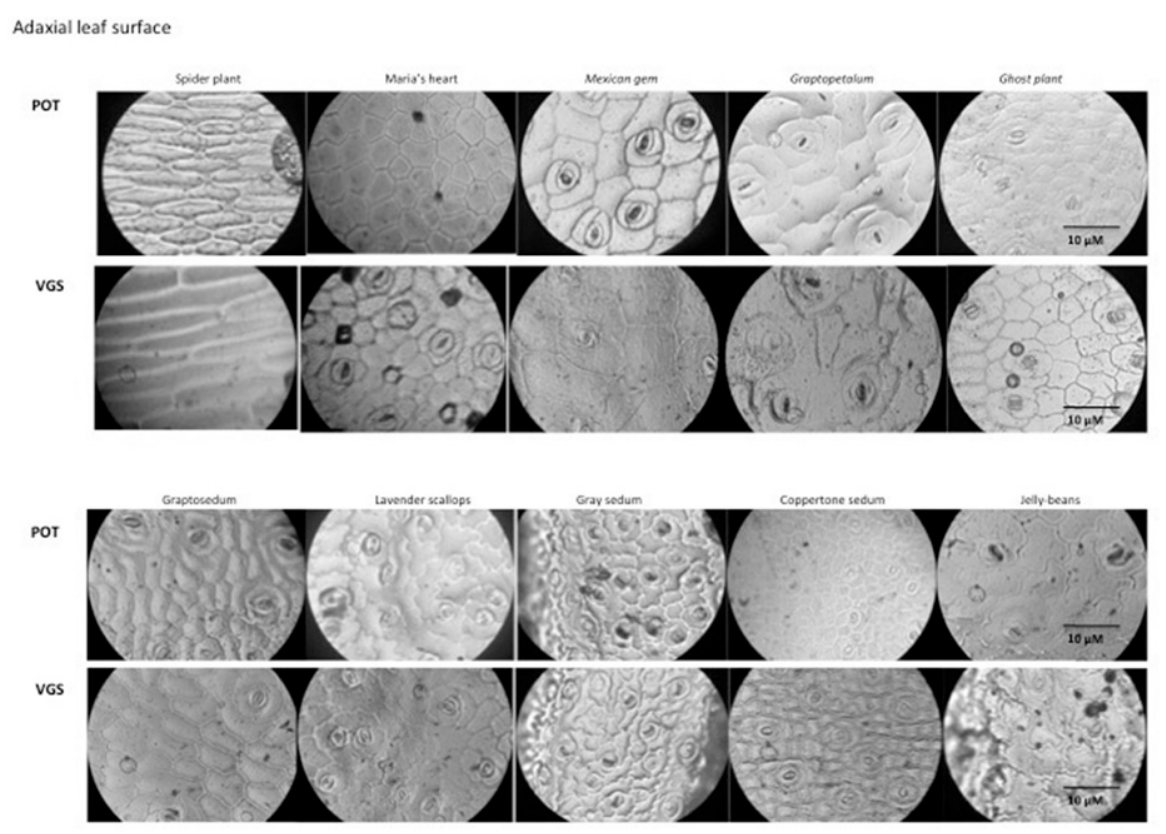

Fig. 5. Difference between stomata number in vertical greenery system (VGS) and containers (POT) for adaxial (lower) leaf surface in spider plant, maria's heart, and stonecrop.

leaf length, POT adaxial stomata, and POT leaf length. These values determine the position of each individual plant in terms of SCP1 and SCP2 in the biplot graphic and objectively show the contrasting or similar response of plants in VGS and POT (Fig. 6); they also highlight species that were significantly different in morphological traits between treatments, such as maria's heart (Fig. 5). The interrelation of the data obtained from all traits became evident when both the VGS and POT values of all eight succulent species, spider plant, and maria's heart were plotted 
together. The position of each plant (represented by dots) in the biplot graph shows the difference between VGS and POT. The species that shows a clear separation based on the variables associated with SCPl (stomata) were maria's heart, gray sedum, and graptopetalum. Several authors have reported changes in morphology and function of crassulacean acid metabolism (CAM) plants based on the study of these plants in different environments. The results agreed with the study of Lüttge (2004) that mentions general changes in phenotype produced by changes in light, water, and temperature provided to the plants, as well as responses to deficits in those elements (Winter and Holtum, 2014).

\section{Conclusions}

Leaves are more sensitive to environment than other components of the plant. They also act as receivers of external signals and can react in response to the ability of roots for water uptake and mineral supplies. The morphological traits in leaves studied here show that mexican gem, graptosedum, lavender scallop, coppertone sedum, ghost plant, and jelly-beans were the species that did not change significantly their morphological traits during growth in the VGS. This provides evidence of the potential for these species to be used in green walls or any VGS while maintaining their characteristic shape and beauty.

Graptopetalum, gray sedum, maria's heart, and spider plant showed changes in its morphology during growth in the VGS, meaning a lower potential for adaption to VGS without changes its particular characteristics.

The native environment in which plants originate from influence their genetic basis and the ability of plants to adapt in a system such as VGS. Some of the Mexican native species studied are genetically able to grow under high irradiance, hot temperatures, and low availability of water; these could be the reasons for not changing desired traits as canopy and leaf shape in different environments or grown systems. Mexican gem, graptosedum, lavender scallop, coppertone sedum, ghost plant, and jellybeans are species that can be used in green walls or VGS located outdoors, because its potential showed growing under shadecloth, without irrigation
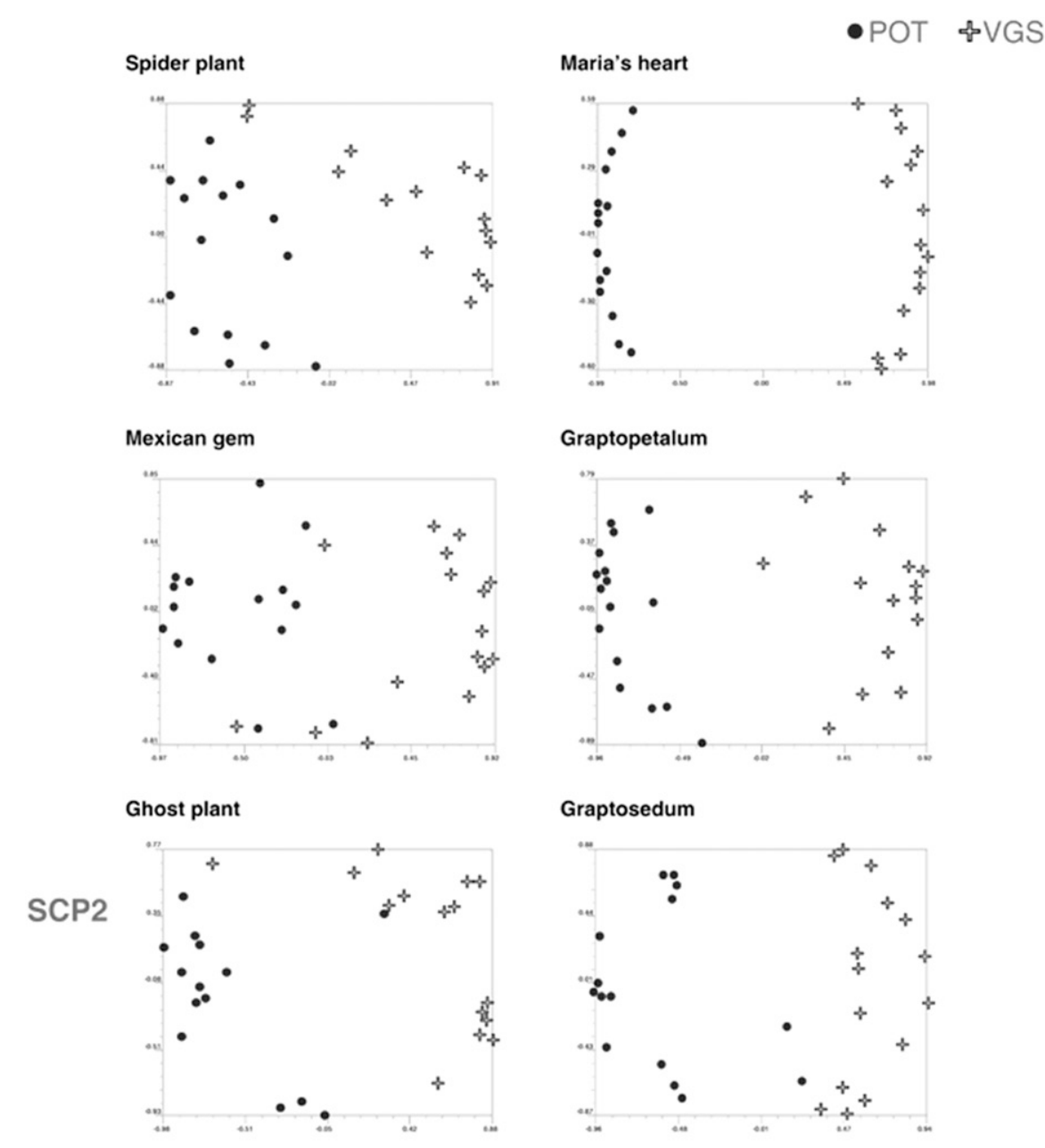

Lavender scallops

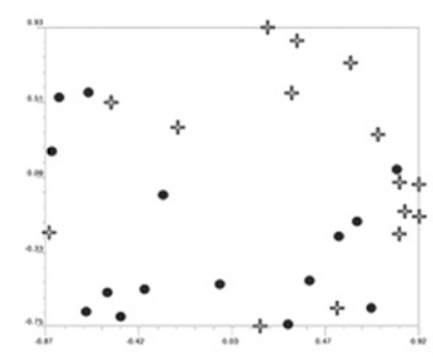

Gray sedum

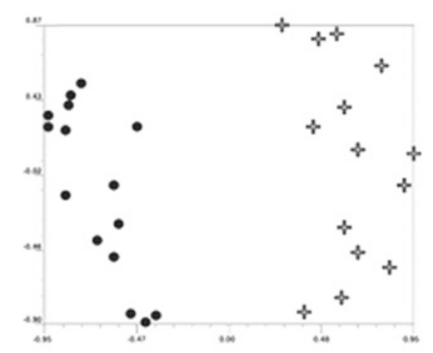

Coppertone sedum

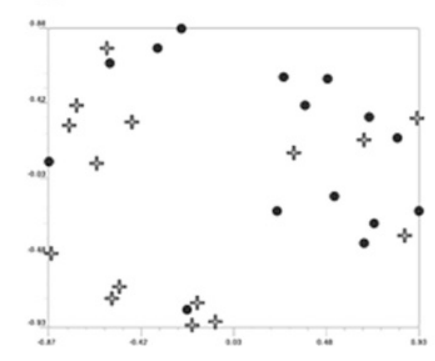

Jelly-beans

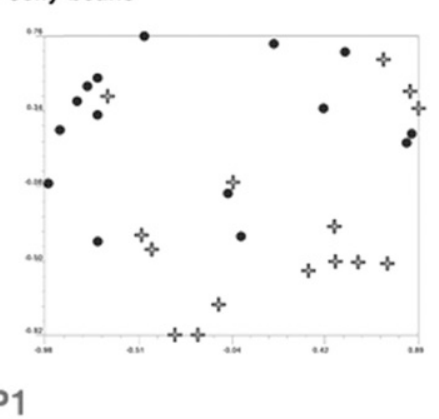

Fig. 6. Biplots demonstrating separation of morphological traits, biomass, and stomata number for stonecrops, spider plant, and maria's heart in the containers (POT) and vertical greenery system (VGS). Score of principal component 1 associates the variables VGS biomass, POT biomass, VGS adaxial (lower) stomata, and POT adaxial stomata. Score of principal component 2 (SCP2) associates VGS adaxial stomata, VGS leaf length, POT adaxial stomata, and POT leaf length. 
system and in the dry season. As with all new technology, there is a requirement for further testing and detailed investigation in various climates to optimize the VGS and to explore new applications of this technology.

\section{Literature cited}

AbdulRahaman, A.A., O.S. Kolawole, and F.A. Oladele. 2014. Leaf epidermal features as taxonomic characters in some Lannea spieces (Anacardiaceae) from Nigeria. Phytologia Balcanica 20:227231.

Abrahamson, W.G. and H. Caswell. 1989. On the comparative allocation of biomass, energy, and nutrients in plants. Ecology 63:982-991.

Bartesaghi-Koc, C., P. Osmond, and A. Peters. 2017. Towards a comprehensive green infrastructure typology: A systematic review of approaches, methods and typologies. Urban Ecosyst. 20:15-35.

Blanc, P. 2008. The vertical garden: From nature to the city. Norton, New York, NY.

Bradshaw, A.D. and K. Hardwick. 1989. Evolution and stress-Genotypic and phenotypic components. Biol. J. Linn. Soc. 37:137-155.

Brzezicka, E., K. Karwowska, M. KozieradzkaKiszkurno, and M. Chernetskyy. 2015. Leaf micromorphology of Kalanchoë laciniata (Crassulaceae). Mod. Phytomorphol. $8: 49-52$

Coma, J., G. Pérez, A. de Gracia, S. Burés, M. Urrestarazu, and L.F. Cabeza. 2016. Vertical greenery systems for energy savings in buildings: A comparative study between green walls and green facades. Build. Environ. 111:228-237.

Gasperi, D., G. Bazzocchi, I. Bertocchi, S. Ramazzotti, and G. Gianquinto. 2015. The multifunctional role of urban gardens in the twentieth century. The Bologna case study. Chronica Hort. 1095:91-98.

Gay, A.P. and R.G. Hurd. 1975. The influence of light on stomatal density in the tomato. New Phytol. 75:37-46.
Givnish, T.J. 1988. Adaptation to sun and shade: A whole-plant perspective. Austral. J. Plant Physiol. 15:63-92.

Hetherington, A.M. and F.I. Woodward. 2003. The role of stomata in sensing and driving environmental change. Nature 424:901-908.

Kottek, M., J. Grieser, C. Beck, B. Rudolf, and F. Rubel. 2006. World map of the Köppen-Geiger climate classification updated. Meteorologische Zeitschrift 15:259263.

Lüttge, U. 2004. Ecophysiology of crassulacean acid metabolism (CAM). Ann. Bot. 93:629-652.

Manso, M. and J. Castro-Gomes. 2015. Green wall system: A review of their characteristics. Renew. Sustain. Energy Rev. 41:863-871.

McFarland, A. 2017. The relationship between the use of green spaces and public gardens in the work place on mental well-being, quality of life, and job satisfaction for employees and volunteers. HortTechnology 27:187-198.

Medl, A., R. Stangl, S.B. Kikuta, and F. Florineth. 2017. Vegetation establishment on 'Green Walls': Integrating shotcrete walls from road construction into the landscape. Urban For. Urban Green. $25: 26-35$

Nagase, A. and N. Dunnett. 2010. Drought tolerance in different vegetation types for extensive green roofs: Effects of watering and diversity. Landsc. Urban Plan. 97:318-327.

Nobel, P.S., L.J. Zaragoza, and W.K. Smith. 1975. Relation between mesophyll surface area, photosynthesis rate and illumination level during development for leaves of Plectanthrus parviflorus $\mathrm{H}$. Plant Physiol. 55:2067-2070.

Pérez, G., J. Coma, I. Martorell, and L.F. Cabeza. 2014. Vertical greenery systems (VGS) for energy saving in buildings: A review. Renew. Sustain. Energy Rev. 39:139-165.

Perini, K., M. Ottelé, E.M. Haas, and R. Raiteri. 2011. Greening the building envelope, façade greening and living wall systems. Open J. Ecol. 1:1-8.

Razzaghmanesh, M., S. Beechman, and F. Kazemi. 2014. The growth and survival of plants in urban green roofs in a dry climate. Sci. Total Environ. 476-477:288297.

Rohlf, F.J. 2009. NTSYSpc. Numerical taxonomy system. Ver. 2.21 c. Exeter Software, Setauket, NY.

Silva, E.C., R.J.M.C. Nogueira, F.H.A. Vale, F.P. de Araujo, and M. Pimenta. 2009. Stomatal changes induced by intermittent drought in four umbu tree genotypes. Braz. J. Plant Physiol. 21:3342

Silva, H., S. Sagardia, M. Ortiz, N. Franck, M. Opazo, M. Quiroz, C. Baginsky, and C. Tapia. 2014. Relationships between leaf anatomy, morphology, and water use efficiency in Aloe vera (L) Burm $\mathrm{f}$. as a function of water availability. Rev. Chil. Hist. Nat. 87:1-13.

Sultan, S.E. 1995. Phenotypic plasticity and plant adaptation. Acta Bot. Neerl. $44: 363-383$

Teeri, J.A., S.J. Tonsor, and M. Turner. 1981. Leaf thickness and carbon isotope composition in the Crassulaceae. Oecologia 50:367-369.

Timur, Ö.B. and E. Karaca. 2013. Vertical gardens, p. 587-622. In: M. Özyavuz (ed.). Advances in landscape architecture. InTech, London, UK.

van den Berg, A.E. and M.M.H.E. van den Berg. 2015. Health benefits of plants and green space: Establishing the evidence base. Acta Hort. 1093:19-30.

Winter, K. and J.A.M. Holtum. 2014. Facultative crassulacean acid metabolism (CAM) plants: Powerful tools for unravelling the functional elements of CAM photosynthesis. J. Expt. Bot. 65:34253441 .

Wolf, K.L. 2015. Metro nature for mental health and wellness: Horticulture secondary benefits. Chronica Hort. 1093:5-10. 